\title{
Hydrotalcite Catalyst for Hydrocracking Calophyllum inophyllum Oil to Biofuel: A Comparative Study with and without Nickel Impregnation
}

\author{
H. Hafshah, Danawati Hari Prajitno*, Achmad Roesyadi \\ Laboratory of Chemical Reaction Engineering, Department of Chemical Engineering, \\ Faculty of Industrial Technology, Sepuluh Nopember Institute of Technology, Surabaya 60111, \\ East Java, Indonesia
}

Received: 15 th November 2016; Revised: 22 ${ }^{\text {nd }}$ February 2017; Accepted: 22 ${ }^{\text {nd }}$ February 2017

\section{Abstract}

This research aims to study the effect of nickel impregnation into hydrotalcite catalyst that use to convert Calophyllum inophyllum oil into biofuel through hydrocracking process. Hydrocracking process was carried out under mild condition $\left(350{ }^{\circ} \mathrm{C}\right.$ and 20 bar) for two hours in a slurry batch reactor. The adding nickel affected the reaction conversion, yield, and selectivity of gasoil. The process of oxygen removal from the compounds in the oil was characterized by Fourier Transform Infrared Spectroscopy (FTIR), and the compositions of the products were determined by Gas Chromatography-Mass Spectrometry (GC-MS). The results of the study successfully proved that nickel impregnated into hydrotalcite catalyst increased the conversion, yield, and selectivity of gasoil up to $98.57 \%, 54.15 \%$, and 81.31 \%, respectively. Copyright (C) 2017 BCREC Group. All rights reserved

Keywords: Biofuel; Calophyllum inophyllum oil; Hydrocracking; Hydrotalcite; Nickel

How to Cite: Hafshah, H., Prajitno, D.H., Roesyadi, A. (2017). Hydrotalcite Catalyst for Hydrocracking Calophyllum inophyllum Oil to Biofuel : A Comparative Study with and without Nickel Impregnation. Bulletin of Chemical Reaction Engineering \& Catalysis, 12 (2): 273-280 (doi:10.9767/bcrec.12.2.776.273-280)

Permalink/DOI: http://dx.doi.org/10.9767/bcrec.12.2.776.273-280

\section{Introduction}

Energy has become the basic needs of peoples in the world. It is necessary to find the renewable sources of energy that can be optimized. Various methods are used to fill up the increasing energy needs around the world. One concern is biofuel; where the biofuels are characterized by good cold flow properties, the proper ratio of hydrocarbons (n-alkanes, isoalkanes, cycloparaffins, and aromatics) and highenergy density [1]

* Corresponding Author.

E-mail: dana@chem-eng.its.ac.id (Prajitno, D.H.)
The use of non-edible oils, such as jatropha oil, rubber seed oil, and Calophyllum inophyllum oil as a source of biofuel, can be the best option in order not conflict with food needs. The compounds of triglycerides contain hydrocarbon chains that similar to petroleum. The removal of oxygen needs to be done in the form of $\mathrm{CO}, \mathrm{H}_{2} \mathrm{O}$, and $\mathrm{CO}_{2}$ to produce paraffin liquid biofuel that can be used directly in the existing infrastructure without modification [2,3].

Through the hydroprocessing process, it can be used to remove oxygen from triglyceride oils to obtain diesel range hydrocarbons. There are three pathways in the process, i.e. (1) the first pathway, decarbonylation produces $\mathrm{CO}$ and 
$\mathrm{H}_{2} \mathrm{O}$, (2) the second pathway, decarboxylation produces $\mathrm{CO}_{2}$, and (3) the last pathway, hydrodeoxygenation produces $\mathrm{H}_{2} \mathrm{O}$ [4,5]. After removal of oxygen, the process was followed by hydrocracking that breaks carbon-carbon bonds and reduces average molecular weight and produces higher yields of fuel. The type of catalyst can control the route and products from the reaction [6]. Scheme of simple reaction is shown in Figure 1 [7].

Hydrotalcites, magnesium - aluminum hydrocarbonate $\left(\mathrm{Mg}_{6} \mathrm{Al}_{2}(\mathrm{OH})_{16} \mathrm{CO}_{3 .} 4 \mathrm{H}_{2} \mathrm{O}\right)$ are minerals from anionic clays family. It contains $\mathrm{M}^{2+}$ and $\mathrm{M}^{3+}$ metal cation in hydroxide layers and anion in the interlamellar space. Hydrotalcite exhibited high surface area after thermal degradation by calcination and formed $\mathrm{MgO}$ [8]. It has great variety and was used as heterogeneous catalyst and adsorbents. The common method to prepare the hydrotalcite is by coprecipitation at low supersaturation because it produces more crystalline compare to high supersaturation. Romero et al. [9] tested decarboxylation of Jatropha curcas oil under a nitrogen atmosphere by hydrotalcite (Pural MG70) catalyst at $350{ }^{\circ} \mathrm{C}$ and $400{ }^{\circ} \mathrm{C}$ with a reaction time of $6 \mathrm{~h}$, in which the yield of $\mathrm{C}_{8}-\mathrm{C}_{18}$ was about $83 \%$.

Calophyllum inophyllum seed productivity is higher compared to other plants, such as jatropha and palm, where Calophyllum inophyl- lum plant productivity reached 20 tons/ha/year while the jatropha only five tons/ha/year and palm six tons/ha/year. Therefore, Calophyllum inophyllum are potentially used as an alternative fuel in the future [11]. In addition to that, Calophyllum inophyllum seeds have an oil content of 55-75\% [12,13], kernel seeds contain of $3.3 \%$ water, and $71.4 \%$ of oil, when fresh seeds contain $55 \%$ of oil whereas the dry seeds about $70.5 \%$ of the oil.

The metal catalyst transition has an important role in the process of hydrocracking. The metals, i.e. Ni, NiMo, CoMo, Pd, and Pt, are the common catalysts for hydrotreating vegetable oil. Rasyid et al. [14] studied the hydrocracking of Calophyllum innophylum kernel oil over non-sulfide CoMo. It converted into fuels, such as gasoline, kerosene, and gasoil, under temperature of $350{ }^{\circ} \mathrm{C}$, pressure of $30 \mathrm{bar}$, and catalyst weight of $5 \%$. The study resulted in the conversion of $99.9 \%$ and selective to gasoil. Wang et al. [5] studied hydrotreatment of soybean oil to produce diesel alkanes ranged over $\mathrm{Ni} / Z$ eolite, the conversion of soybean oil was $100 \%$ over $8 \mathrm{wt} \% \mathrm{Ni} / \mathrm{SAPO}-11$ catalyst at 370 ${ }^{\circ} \mathrm{C}, 4 \mathrm{MPa}$, and 1 hour reaction time. The method of impregnation of $\mathrm{Ni}$ has been selected because it has good activity in hydrogenation, and the cost of $\mathrm{Ni}$ is $\sim 1000$ and $\sim 2500$ times lower than Pd and Pt [15]. Morgan et al. [16] also proved that Ni-based catalysts were highly

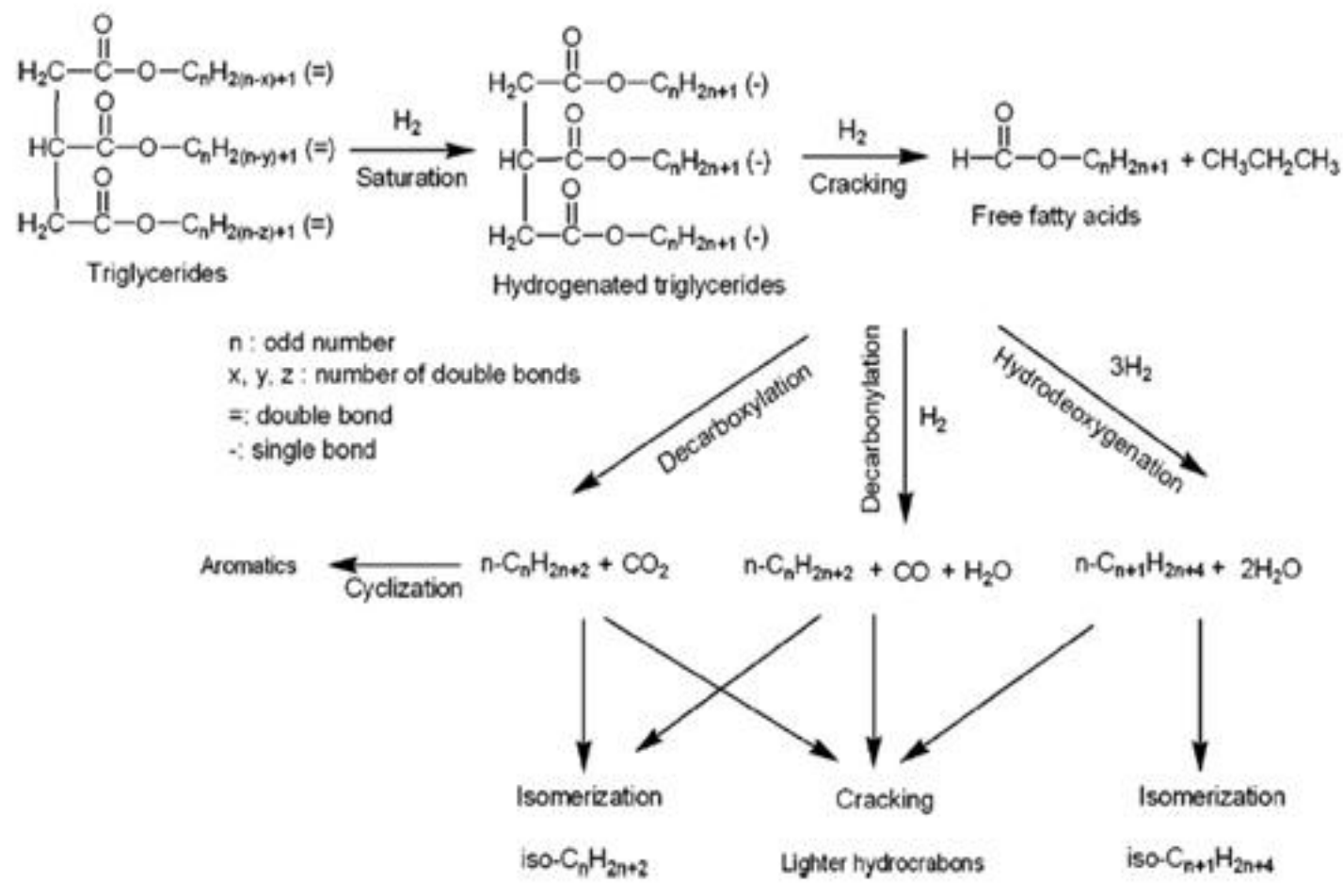

Figure 1. The possible pathways to produce biofuel [7] 
active for upgrading vegetable oil in batch reactors.

In the view of above, there has been no study of hydrocracking that uses pure hydrotalcite and nickel impregnated into hydrotalcite catalysts. The last previous study reported hydrocracking over hydrotalcite (MG70) at high temperature $\left(400{ }^{\circ} \mathrm{C}\right)$ and without hydrogen in the process [9]. In this study, hydrocracking of Calophyllum inophyllum oil was conducted in a slurry batch reactor at mild temperature of 350 ${ }^{\circ} \mathrm{C}$ under hydrogen atmosphere over hydrotalcite and Ni/Hydrotalcite catalysts. This research intends to study the effect of nickel impregnation towards the effectiveness of hydrocracking process.

\section{Materials and Methods}

\subsection{Materials}

Calophyllum inophyllum oil was obtained from local farmer in Kroya, Cilacap, Central Java, Indonesia. It was directly used for hydrocracking without any pretreatment. The raw materials for synthesis hydrotalcite were grade PA of Magnesium Nitrate Hexahydrate $\left(\mathrm{Mg}\left(\mathrm{NO}_{3}\right)_{2} .6 \mathrm{H}_{2} \mathrm{O}\right)$ (Merck, 99 \%), Aluminium Nonahydrate $\left(\mathrm{Al}\left(\mathrm{NO}_{3}\right)_{3} .9 \mathrm{H}_{2} \mathrm{O}\right)$ (Merck $98.5 \%$ ), Natrium hydroxide ( $\mathrm{NaOH}$ ) (Merck, $99 \%$ ), Natrium Carbonate $\left(\mathrm{Na}_{2} \mathrm{CO}_{3}\right)$ (Merck, $99.5 \%$ ). Nickel Nitrate Hexahydrate $\left(\mathrm{Ni}\left(\mathrm{NO}_{3}\right)_{2} .6 \mathrm{H}_{2} \mathrm{O}\right)$ (Merck, $98 \%$ ) solution for impregnation.

\subsection{Methods}

\subsubsection{Preparation of catalyst}

Hydrotalcite catalyst was prepared by low supersaturation coprecipitation method, followed by incipicient wetness impregnation methods to produce $\mathrm{Ni} / \mathrm{Hydrotalcite}$ catalyst. In the impregnation method, the solution of nickel nitrate hexahydrate $\left(\mathrm{Ni}\left(\mathrm{NO}_{3}\right)_{2} .6 \mathrm{H}_{2} \mathrm{O}\right) \quad(10 \%)$ was used appropriate with pore volume of the support catalyst. The $\mathrm{Ni} / \mathrm{Hydrotalcite}$ was dried in an oven at $110{ }^{\circ} \mathrm{C}$ for 12 hours and followed by calcination for 3 hours at $400{ }^{\circ} \mathrm{C}$ and reduction for 2 hours at $450{ }^{\circ} \mathrm{C}$ with hydrogen.

\subsubsection{Catalyst characterization}

X-Ray diffraction (XRD) patterns for hydrotalcite were obtained in the $2 \theta$ range $=5-90^{\circ}$ using PAN Analytical X'Pert PRO X-ray Diffractometer with $\mathrm{Cu}-\mathrm{Ka}$ radiation source and operating at $40 \mathrm{kV}$ and $30 \mathrm{~mA}$. The XRD patterns were compared with JCPDS data for material identification. The $\mathrm{N}_{2}$ adsorption isotherms at $77.3 \mathrm{~K}$ analyzes the textural parame- ter of supports and catalysts such as surface area, pore volume, and average pore diameter. The surface area (S Brunauer Emmett Teller (BET) using Quantachrome NovaWin Version 10.0 based upon the adsorption data with partial pressure $(P / P o)$, range of $0.0990-0.3006$ through recording process of isotherm of BET on 5 points. Pore size distribution was calculated by BarretJoyner Halenda (BJH) and total pore volumes was calculated from the amount of nitrogen adsorbed at $P / P o=0.99789$.

\subsubsection{Hydrocracking process}

The reactions were conducted in slurry batch reactor equipped with mechanical stirrer under mild condition at temperature of $350{ }^{\circ} \mathrm{C}$ and pressure of 20 bar. The $200 \mathrm{~mL}$ of Calophyllum inophyllum oil was introduced into the reactor with $5 \mathrm{~g}$ of catalyst and then purged with nitrogen to remove remaining oxygen from reactor. The reaction took time about $2 \mathrm{~h}$ in the presence of hydrogen.

\subsubsection{Characterization of Calophyllum ino- phyllum oil and the liquid products}

The chemical composition of liquid products was investigated by Thermoscientific Nicolet IS10 FTIR Spectrometer. The component of liquid products biofuel was analyzed by using Gas Chromatography-Mass Spectrometry (GCMS, Agilent HP 6890 and models 19091S-433, HP-5MS) with a hydrogen flow rate of 1.0 $\mathrm{mL} / \mathrm{min}$. The capillary column was a $30 \mathrm{~m} \times$ $250 \mu \mathrm{m} \times 0.25 \mu \mathrm{m}$ DB-5MS. The $1.0 \mu \mathrm{L}$ of hydrocarbon biofuel was introduced to the GC-MS through an injection port operated in a splitless mode at $300{ }^{\circ} \mathrm{C}$. The gas chromatograph was programmed at nominal initial pressure of $13.3 \mathrm{psi}$ and temperature at $150{ }^{\circ} \mathrm{C}$ for $2 \mathrm{~min}$, then it increased to $240{ }^{\circ} \mathrm{C}$ at the rate of $10{ }^{\circ} \mathrm{C} / \mathrm{min}$ for $11 \mathrm{~min}$. The major components of hydrocarbon biofuel were identified through a National Institute of Standards and Technology (NIST02) mass spectra library and wileys 275 . The relative content of the components was determined based on the GC-MS peak area.

The effectiveness of hydrocracking Calophyllum inophyllum over hydrotalcite catalyst can be seen from conversion as the percentage of the oil feed product which has been converted into biofuel products (Equation 1).

$$
\text { Conversion }(\%)=\frac{\text { Feed }_{\text {Cbx.acid }}-\text { Product }_{\text {Cbx.acid }}}{\text { Feed }} \text { Cbx.acid }_{100}
$$


where Feedcbx.acid and Productcbx.acid are the area $\%$ of the feed and product, which are carboxylic acids. The yields of the three different products of biofuel, gasoline, kerosene, and gasoil, were estimated from area\% of liquid product that has carbon number $\mathrm{C}_{5}-\mathrm{C}_{8}$ (gasoline), $\mathrm{C}_{9}-\mathrm{C}_{13}$ (kerosene), $\mathrm{C}_{14}-\mathrm{C}_{22}$ (gasoil). Furthermore, the effectiveness of hydrotalcite and nickel to produce a particular product were calculated based on selectivity (Equation 2).

$$
\text { Selectivity }(\%)=\frac{\text { Product }_{A}-\text { Feed }_{A}}{\text { Feed }_{\text {Cbx.acid }}-\text { Product }_{\text {Cbx.acid }}} x 100
$$

\section{Results and Discussion}

\subsection{Catalyst characterization}

Textural properties of hydrotalcite employed in this hydrocracking reaction were summarized in Table 1. Besides of analysis of surface area, nitrogen adsorption-desorption method was also conducted to determine the type of adsorption-desorption isotherm to describe the pores of the catalyst. The adsorption-desorption isothermal curves are shown in Figure 2. Based on the classification of IUPAC (International Union of Pure and Applied Chemistry in) adsorption-desorption of hydrotalcite shows the isothermal type IV. In Figure 2, the adsorption starting at $P / P_{0}=0$ to 1 , it appeared that at $P / P_{0}=0$ very little gas was adsorbed, and the area has not been a full in monolayer. When the pressure was raised again until the $P / P_{0}=$ 0.5 multilayer adsorption was taking place, but the amount not much that's why the increase in the graph was still not too sharp. After the application of higher pressure, $P / P_{0}=1$, caused gas molecules fulfilled the mesoporous, and isothermal curve sharply rose because of the large amount of adsorbed gas.

Figure 3 shows the pore size distribution of hydrotalcite with BJH method (Barret, Joiner, Halenda). It observed that the bimodal peaks showed the presence of two groups that each pore size was the pore diameter of about 3.42 and $4.27 \mathrm{~nm}$ with a percentage of $34.75 \%$ of the total volume. Overall, it can be concluded that the pore diameters of the samples were in the size range of mesoporous $(2-50 \mathrm{~nm})$, so that the hydrotalcite samples was mesoporous solids.

Catalyst with large pore size, such as mesoporous, has better thermal stability compare to microporous size, because it posses thick walls, uniform and hexagonal structured channel [15]. The mesoporous catalyst performance in hydrocracking gives high selectivity to diesel, low gas products, and high cokes because of low acidity and high pore volume.

XRD pattern of calcined hydrotalcite with metal (nickel) in Figure 4 shows two main peaks at $2 \theta$ of $36.95^{\circ}$ and $42.91^{\circ}$ corresponded to the diffraction of $\mathrm{MgO}$, while peak of $\mathrm{NiO}$

Table 1. Textural properties of hydrotalcite

\begin{tabular}{lccc}
\hline Sample & S BET $\left(\mathrm{m}^{2} \mathrm{~g}^{-1}\right)$ & Pore Volume $\left(\mathrm{cm}^{3} \mathrm{~g}^{-1}\right)$ & Average Diameter Pore $(\mathrm{nm})$ \\
\hline Hydrotalcite & 190.166 & 0.7714 & 16.226 \\
\hline
\end{tabular}

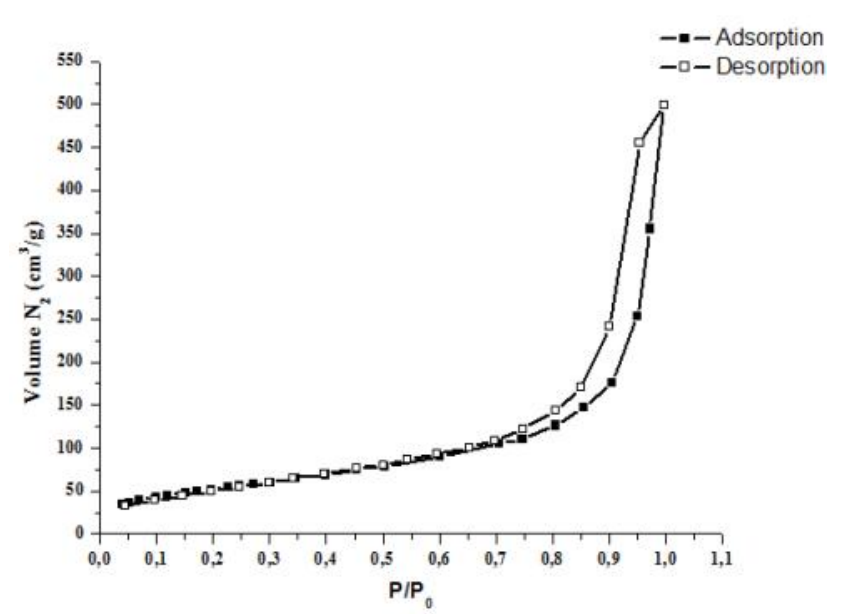

Figure 2. $\mathrm{N}_{2}$ adsorption/desorption isotherms of hydrotalcite after calcination



Figure 3. Pore size distribution of hydrotalcite after calcination 
was detected at $2 \theta$ of $37.25^{\circ}$ and $43.27^{\circ}$, and $\mathrm{Ni}$ at $44.6^{\circ}$. In fact, the most intense diffraction data of $\mathrm{NiO}$ almost overlaps at about $37.25^{\circ}$ and $43.27^{\circ}$ with the most intense peak of $\mathrm{MgO}$, but the presence of diffraction peak of $\mathrm{Ni}$ at $44.6^{\circ}$ was detectable with small intensity.

\subsection{Hydrocracking reaction of Calophyl- lum inophyllum oil over hydrotalcite and Ni/hydrotalcite}

3.2.1. Characterization of the feeds and liquid products

The results of GC-MS analysis of Calophyllum inophyllum oil showed two dominant fatty acids as shown in Table 2. Palmitic acid appeared in retention time 9 minutes and oleic acid at the retention time of 11-12 minutes (Figure 5). A high content of oleic acid is potential to be converted into biofuel through hydrocracking. Results of analysis of Calophyllum inophyllum oil was similar to the studied by other researchers [17,12], stated that the Calophyllum inophyllum oil contains unsaturated fatty acid (oleic acid) in an amount greater than other fatty acids. Liquid product of hydrocracking Calophyllum inophyllum oil appeared in a dark, turbid, and distinctive smell liquid. It is because of the carbon deposit formation

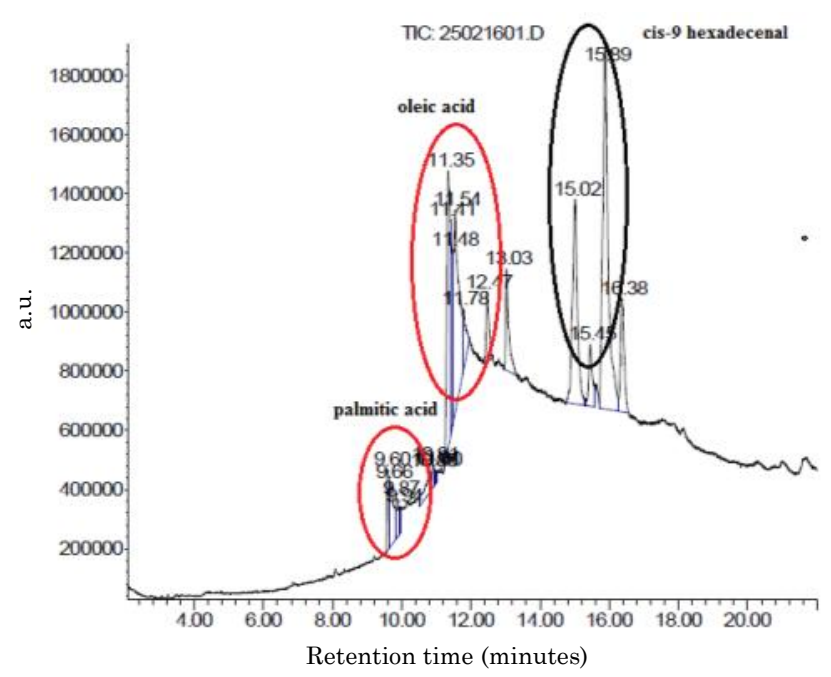

Figure 5. Chromatogram of Calophyllum inophyllum oil during high temperature of hydrocracking. Carbon deposits, known as a coke, was a product from the cation intermediates that more stable and accumulates in the catalyst during the reaction.

\subsubsection{FTIR analysis}

Figure 6 shows the spectra of Calophyllum inophyllum oil as feedstock, biofuel products over hydrotalcite, and $10 \% \mathrm{Ni} / \mathrm{Hydrotalcite}$ catalysts. The FTIR analysis observed the

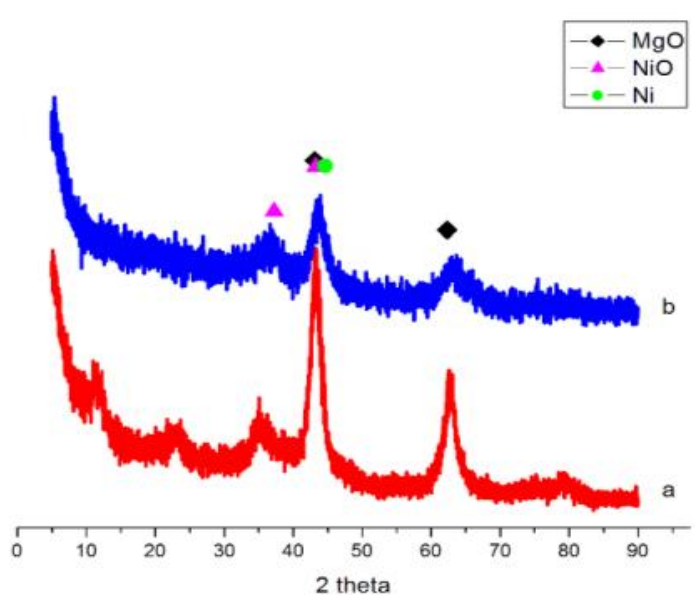

Figure 4. Powder X-ray diffraction patterns of a) Hydrotalcite, b) $10 \% \mathrm{Ni} /$ Hydrotalcite

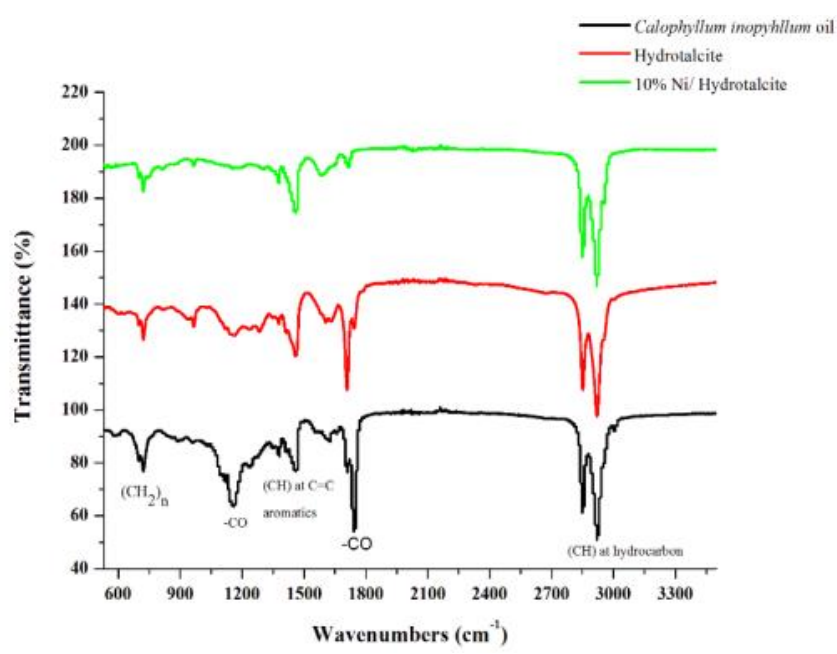

Figure 6. Comparison of FTIR spectra of Calophyllum inophyllum oil, biofuel over hydrotalcite, and $10 \% \mathrm{Ni} /$ hydrotalcite

Table 2. Fatty acid composition of Calophyllum inophyllum oil

\begin{tabular}{lccc}
\hline \multicolumn{1}{c}{ Fatty Acids } & Name & Formula & Relative abundance (\%) \\
\hline $\begin{array}{l}\text { 1. Saturated } \\
\text { Palmitic Acid (C16:0) }\end{array}$ & Hexadecanoic & $\mathrm{C}_{16} \mathrm{H}_{32} \mathrm{O}_{2}$ & 7.93 \\
$\begin{array}{l}\text { 2. Unsaturated } \\
\text { Oleic Acid (C18:1) }\end{array}$ & Cis-9-Octadecenoic & $\mathrm{C}_{18} \mathrm{H}_{34} \mathrm{O}_{2}$ & 50.25 \\
\hline
\end{tabular}


change of the spectra after hydrocracking reaction occurs. The absorbance changed significantly at any kinds of bond between Calophyllum inophyllum oil and biofuel. There were significant changes in the molecular structure.

In analyzing the infrared spectrum of biofuels sample, first observe was focused on the carbon skeleton, because the biofuel was expected to have compounds approaching fraction of petroleum. Hydrocarbon chain appears in the infrared spectrum at various kinds of absorption that caused by the presence of carboncarbon bonds. As mentioned by Pavia et al. [18], the hydrocarbons have a main absorption in the $\mathrm{C}-\mathrm{H}$ area near $3000 \mathrm{~cm}^{-1}$ and was also simple absorption spectrum, which appeared at $1460-1375 \mathrm{~cm}^{-1}$. If there were $\mathrm{C}=\mathrm{C}$, the medium to strong absorption would have detected on the area in 1600-1450 $\mathrm{cm}^{-1}$. This value usually indicates a double bond or aromatic rings. The appearance of the tape at the wave number region of $750-720 \mathrm{~cm}^{-1}$ that are precisely the wave number of $721 \mathrm{~cm}^{-1}$ showed that the alkyl group might contain three neighboring methylene group $\left(-\mathrm{CH}_{2}-\mathrm{CH}_{2}-\mathrm{CH}_{2}-\mathrm{CH}_{2}\right)$.

The spectrum reported in Figure 6 shows that the carbon skeletons can be directly seen in the area of the wave number of $3000-2700$ $\mathrm{cm}^{-1}$, which were the characteristic for the absorption of alkanes. An increasing trend in the alkane compounds, suggesting the formation of paraffin products in biofuels, and - $\mathrm{CO}$ bond spectra on biofuel products weakened due to removal of oxygen in the hydrocracking reaction, as well as the $\mathrm{C}=\mathrm{O}$ bond order to show a decline.

\subsubsection{GC-MS analysis}

Table 3 showed the distribution of liquid products after 2 hours reaction time under 20 bar at temperature of $350{ }^{\circ} \mathrm{C}$ over catalyst of hydrotalcite and with nickel impregnation. The composition products over hydrotalcite catalyst was still an intermediate products in the form of carboxylic acids and fatty acid as constituent of oil, such as stearic acid, which is derived from the saturation of oleic acid as stated by Alwan [19] that the presences of stearic acid were hydrogenated products from some of the oleic acid and linoleic acid. The composition of hydrocarbons were only about $1.62 \%$ and 2.03 $\%$ for gasoline and gasoil, respectively (Table 4), while aromatics and cycloparaffins were not formed, due to that aromatization and cyclization reaction has not occurred yet.

Table 3. Hydrocarbon composition of hydrocracking of Calophyllum inophyllum oil under the condition of $350^{\circ} \mathrm{C}, 20$ bar, 5 g catalyst, and $200 \mathrm{~mL}$ oil

\begin{tabular}{lcccccc}
\hline \multirow{2}{*}{ Catalyst } & \multicolumn{6}{c}{ Composition, \% Area } \\
\cline { 2 - 7 } & n-paraffin & $\begin{array}{c}\text { Cycloparaffin/ } \\
\text { Naphtene }\end{array}$ & Aromatics & $\begin{array}{c}\text { Olefin/ } \\
\text { Alkene }\end{array}$ & $\begin{array}{c}\text { Carboxylic } \\
\text { Acid }\end{array}$ & $\begin{array}{c}\text { Alcohol, } \\
\text { C=O, C-O, } \\
\text { C-OH }\end{array}$ \\
\hline Hydrotalcite & 1.53 & 0.82 & 0.16 & 1.6 & 91.15 & 3.55 \\
$10 \%$ Ni/Hydrotalcite & 46.95 & 10.86 & 9.38 & 19.36 & 3,74 & 8.6 \\
\hline
\end{tabular}

Table 4. Product yield of hydrocracking Calophyllum inophyllum oil under the condition of $350^{\circ} \mathrm{C}, 20$ bar, $5 \mathrm{~g}$ catalyst, and $200 \mathrm{~mL}$ oil

\begin{tabular}{lccc}
\hline \multirow{3}{*}{ Catalysts } & \multicolumn{3}{c}{ Yield, wt (\%) } \\
\cline { 2 - 4 } & Gasoline & Kerosene & Gasoil \\
& $\mathrm{C}_{5}-\mathrm{C}_{8}$ & $\mathrm{C}_{9}-\mathrm{C}_{13}$ & $\mathrm{C}_{14}-\mathrm{C}_{22}$ \\
\hline Hydrotalcite & 0 & 1.62 & 2.03 \\
$10 \%$ Ni/Hydrotalcite & 0.97 & 2.66 & 54.15 \\
\hline
\end{tabular}

Table 5. The influence of the catalyst on conversion, selectivity, and product ratio of hydrocracking Calophyllum inophyllum oil

\begin{tabular}{ccccc}
\hline Catalyst & Conversion (\%) & Selectivity to gasoil (\%) & $\mathrm{C}_{17} / \mathrm{C}_{18}$ Ratio & $\mathrm{C}_{15} / \mathrm{C}_{16}$ Ratio \\
\hline 0/HTC & 41.99 & 7.07 & 0 & 2.47 \\
$10 \mathrm{Ni} / \mathrm{HTC}$ & 98.57 & 81.31 & 14.76 & 2.54 \\
\hline
\end{tabular}


The biofuels contain hydrocarbon and a certain amount of oxygenated compounds, such as acids, alcohols, and aldehyde. It shows low activity of hydrotalcite as hydrocracking catalysts due to the low acidity of hydrotalcite and also lack at the time needed to assist reaction hydrocracking over hydrotalcite. This finding is consistent with Romero et al. [9] that reported high conversion of more than $80 \%$ by using hydrotalcite with reaction time of six hours. Morgan et al. [14] used $\mathrm{Ni}-\mathrm{Al} \mathrm{LDH}$ and $20 \%$ $\mathrm{Ni} / \mathrm{Al}_{2} \mathrm{O}_{3}$ to convert stearic acid into hydrocarbons with conversion of $42 \%$ and $80 \%$, respectively. The selectivity of Ni-Al $\mathrm{LDH}$ and $20 \%$ $\mathrm{Ni} / \mathrm{Al}_{2} \mathrm{O}_{3}$ of the $\mathrm{C}_{10}-\mathrm{C}_{17}$, were $43 \%$ and $85 \%$, respectively.

The different results were obtained when hydrotalcite was impregnated with nickel and used as a catalyst in the same operation condition. The composition of liquid products shows a large increase on the number of n-paraffin, cycloparaffin, olefin, aromatics. The composition of hydrocarbon contains gasoline $(0.97 \%)$, kerosene (2.66 \%), and gasoil (54.15\%) (Table 4). These results suggest that the reaction of hydrogenolysis, cyclization, and aromatization were already occurred, while the reaction of isomerization was not happened. It is caused by the low reaction temperature, low acidic catalyst, and longer need of the reaction time. It agrees with Mohammad et al. [1] stated that the hydrocracking reaction was strongly influenced by reaction temperature, pressure, liquid hourly space velocity, and the catalyst. The number of carboxylic acids were also significantly reduced after the addition of nickel showing the removal of oxygen through the reaction of hydrodeoxygenation, decarboxylation, and decarbonylation.

The catalytic performances of hydrotalcite and $\mathrm{Ni} /$ Hydrotalcite catalysts are shown Table 5. Conversion reaction of hydrocracking Calophylum Inophyllum oil increased with the addition of nickel in support of hydrotalcite from $41.99 \%$ over hydrotalcite catalyst, and increased to $98.57 \%$ while over $10 \%$ $\mathrm{Ni} /$ Hydrotalcite catalyst. This results agreed with Roesyadi [20] as the previous researcher proved that impregnation of $\mathrm{Ni}, \mathrm{Cu}$, and $\mathrm{Zn}$ into HZSM- 5 catalyst could increase the active site and surface area of the catalyst. Its due to the higher cracking activity of catalyst. The $\mathrm{Ni} /$ Hydrotalcite catalyst has a high selectivity to gasoil, and the adding $10 \mathrm{wt} \%$ nickel to hydrotalcite increased the selectivity up to 81.31 $\%$ from $7.07 \%$ when using the hydrotalcite.

The main component of gasoil was unsaturated $\mathrm{C}_{17}$, which rose sharply after the addition of nickel into hydrotalcite. The ratio of product of hydrocarbon with an odd carbon number is presented in Table 5, which was derived from the decarboxylation and decarbonylation reactions. As the reaction scheme in Figure 1, it shows that decarboxylation produces hydrocarbon with an odd carbon number at hydrodeoxygenation of even carbon number. In agreement with the results of Roesyadi [20] that nickel tailored a diesel product and decarboxylation reaction.

\section{Conclusions}

Calophyllum inophyllum oil can be converted to produce hydrocarbon biofuel over hydrotalcite catalyst. Impregnation of nickel into the catalyst could increased the conversion, yield, and selectivity of gasoil up to $98.57 \%$, $54.15 \%$, and $81.31 \%$, respectively. The increasing conversion reaction and the yield of gas oil showed that the nickel addition could increase the active sites at the catalyst surface and increase the yield of biofuel products, especially gas oil.

\section{Acknowledgments}

The authors gratefully acknowledge funding from DP2M-DIKTI as grants of Pendukung Unggulan Perguruan Tinggi. Thanks to Chemical Reaction Engineering Laboratory, Department of Chemical Engineering, Faculty of Industrial Technology, Sepuluh Nopember Institute of Technology.

\section{References}

[1] Mohammad, M., Kandaramath Hari, T., Yaakob, Z., Chandra Sharma, Y., Sopian, K., (2013). Overview on the Production of Paraffin Based-Biofuels via Catalytic Hydrodeoxygenation. Renewable and Sustainable Energy Reviews. 22: 121-132.

[2] Sotelo-Boyás, R., Liu, Y., Minowa, T., (2011). Renewable Diesel Production from the Hydrotreating of Rapeseed Oil with Pt/Zeolite and $\mathrm{NiMo} / \mathrm{Al}_{2} \mathrm{O}_{3}$ Catalysts. Industrial \& Engineering Chemistry Research 50: 2791-2799.

[3] Fréty, R., da Rocha, M. da G.C., Brandão, S.T., Pontes, L.A., Padilha, J.F., Borges, L.E., Gonzalez, W.A., (2011). Cracking and Hydrocracking of Triglycerides for Renewable Liquid Fuels: Alternative Processes to Transesterification. Journal of the Brazilian Chemical Society, 22: 1206-1220.

[4] Zarchin, R., Rabaev, M., Vidruk-Nehemya, R., Landau, M.V., Herskowitz, M., (2015). Hydroprocessing of Soybean Oil on Nickel- 
Phosphide Supported Catalysts. Fuel, 139: 684-691.

[5] Wang, C., Liu, Q., Song, J., Li, W., Li, P., Xu, R., Ma, H., Tian, Z., (2014). High Quality Diesel-Range Alkanes Production via a SingleStep Hydrotreatment of Vegetable Oil over Ni/Zeolite Catalyst. Catalysis Today, 234: 153-160.

[6] Palanisamy, S., Gevert, B.S. (2011). Thermal Treatment of Rapeseed oil, in: Bioenergy Technology. World Renewable Energy Congress, a v a i a b l e a t : http://www.ep.liu.se/ecp/057/vol1/073/ecp57vol 1_073.pdf

[7] Veriansyah, B., Han, J.Y., Kim, S.K., Hong, S.-A., Kim, Y.J., Lim, J.S., Shu, Y.-W., Oh, S.G., Kim, J. (2012). Production of Renewable Diesel by Hydroprocessing of Soybean Oil: Effect of Catalysts. Fuel, 94: 578-585.

[8] Gomes, J.F.P., Puna, J.F.B., Gonçalves, L.M., Bordado, J.C.M. (2011). Study on the Use of $\mathrm{MgAl}$ Hydrotalcites as Solid Heterogeneous Catalysts for Biodiesel Production. Energy. 36: $6770-6778$.

[9] Romero, M., Pizzi, A., Toscano, G., Casazza, A.A., Busca, G., Bosio, B., Arato, E. (2015). Preliminary Experimental Study on Biofuel Production by Deoxygenation of Jatropha Oil. Fuel Processing Technology 137: 31-37.

[10] Tani, H., Hasegawa, T., Shimouchi, M., Asami, K., Fujimoto, K. (2011). Selective Catalytic Decarboxy-Cracking of Triglyceride to Middle-Distillate Hydrocarbon. Catalysis. Today.164: 410-414.

[11] Leksono, B, (2010). Nyamplung Plant Breeding (Calophyllum inophyllum. L) for Raw Materials Biofuel. Intensive Research Report Research and Technology, Ministry of Forestry

[12] Rizwanul Fattah, I.M., Kalam, M.A., Masjuki, H.H., Wakil, M.A., (2014). Biodiesel Production, Characterization, Engine Performance, and Emission Characteristics of Malaysian Alexandrian Laurel Oil. RSC Advances, 4(34): 17787-17796.
[13] Atabani, A.E., César, A.S., (2014). Calophyllum inophyllum L. - A Prospective NonEdible Biodiesel Feedstock. Study of Biodiesel Production, Properties, Fatty Acid Composition, Blending and Engine Performance. Renewable and Sustainable Energy Reviews. 37: 644-655.

[14] Rasyid, R., Prihartantyo, A., Mahfud, M., Roesyadi, A., (2015). Hydrocracking of Calophyllum inophyllum Oil with Non-sulfide CoMo Catalysts. Bulletin of Chemical Reaction Engineering \& Catalysis, 10(1): 61-69.

[15] Taufiqurrahmi, N., Bhatia, S., (2011). Catalytic Cracking of Edible and Non-Edible Oils for the Production of Biofuels. Energy \& Environmental Science. 4: 1087-1112.

[16] Santillan-Jimenez, E., Morgan, T., Lacny, J., Mohapatra, S., Crocker, M. (2013). Catalytic Deoxygenation of Triglycerides and Fatty Acids to Hydrocarbons over Carbon-Supported Nickel. Fuel. 103: 1010-1017.

[17] Sahoo, P.K., Das, L.M., Babu, M.K.G., Naik, S.N. (2007). Biodiesel Development from High Acid Value Polanga Seed Oil and Performance Evaluation in a CI Engine. Fuel. 86: 448-454.

[18] Pavia, D.L., Lampman, G.H and Kriz, G.S. (2001). Introduction to Spectroscopy. 3th ed. USA:Thomson Learning

[19] Alwan, B. Al, Salley, S.O., Ng, K.Y.S. (2015). Biofuels Production from Hydrothermal Decarboxylation of Oleic Acid and Soybean Oil over Ni-Based Transition Metal Carbides Supported on Al-SBA-15. Applied Catalysis A: General. 498: 32-40.

[20] Rosyadi, E. (2012). Conversion of Vegetable Oils into Green Diesel and Green Gasoline with the Process of Hydrocracking and $\mathrm{Hy}$ drotreating Catalyst $\mathrm{NiMo} / \mathrm{Al}_{2} \mathrm{O}_{3}, \mathrm{NiMo} / \mathrm{Al}_{2} \mathrm{O}_{3}$ $\mathrm{SiO}_{2}, \mathrm{NiMo} / \mathrm{SiO}_{2}$, and NiMo/Zeolite. Doctoral Dissertation, Department of Chemical Engineering, Sepuluh Nopember Institute of Technology.

Selected and Revised Papers from The $2^{\text {nd }}$ International Seminar on Chemistry (ISoC 2016) (Surabaya, 26-27 July 2016) (http://chem.its.ac.id/isoc-2016/) after Peer-reviewed by Scientific Committee of ISoC 2016 and Peer-Reviewers of BCREC journal 